проф. др Весна Половина проф. др Маја Ђукановић

Универзитет у Београду

Филолошки факултет

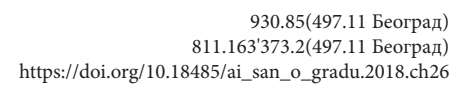

\title{
ГРАД КАО ТЕКСТ
}

На примеру Београда, уз поређење са другим урбаним срединама, желимо да покажемо место појединца или социјалне групе, као и културе кроз свеколике текстове који се могу наћи у граду. С једне стране то су историјско-културолошка слика која се добија кроз називе улица, тргова и других тачака у граду, затим евентуално текстове који се вежу за такве тачке, као и начин на који се стварају кохерентни текстови о урбаном простору.

Кључне речи: текст, град, урбани пејзаж

Увод. У последњих неколико деценија обнавља се интересовање за натписе на јавним местима, имена која означавају објекте у простору, мотивацију за давање имена разним урбаним објектима, другим речима за топономастику, али превасходно, мада не и једино, за градове. Све више се град и оно што пише на зградама, излозима, и свим другим просторима налази као део читалачког штива, нешто са чиме се сусрећу не само пролазници, него све више и стручњаци различитог усмерења. Под заједничким називом тинівистиччки иејзажи (или: језички крајолик - оба термина су калк према енглеском: linguistic landscape) постају предметом истраживања у културној географији, социологији, психологији, историји, антропологији и етнологији, лингвистици и сигурно још неким поддисциплинама у 
оквирима ових широких истраживачких поља. Интердисциплинарност је у овом предмету истраживања готово неминовна. Стварање и давање имена увек зависи и од друштвених, културних, економских, психолошких фактора, те се на топономатсичка сазнања ослањају и науке попут археологије, историје, али је правац утицаја и реципрочан.

Говоређи о апстрактној суштини језичког, па и сваког емиотичког система, о томе да је материјална/супстанцијална страна мање значајна него односи међу језичким јединициама унутар система, а посебно о језичком идентитету и језичкој вредности, де Сосир пореди језик са возним редом и улицом (градом). Погледајмо још једном текст Фердинанда де Cосира,( De Sosir, str. 117).

Ainsi nous parlons d'identité à propos de deux express «Genève-Paris 8 h. 45 du soir » qui partent à vingt-quatre heures d'intervalle. A nos yeux, c'est le même express, et pourtant probablement locomotive, wagons, personnel, tout est différent. Ou bien si une rue est démolie, puis rebâtie, nous disons que c'est la même rue, alors que matériellement il ne subsiste peut-être rien de l'ancienne. Pourquoi peut-on reconstruire une rue de fond en comble sans qu'elle cesse dêtre la même? Parce que l'entité qu'elle constitue n'est pas purement matérielle; elle est fondée sur certaines conditions auxquelles sa matière occasionnelle est étrangère, par exemple sa situation relativement aux autres (de Saussure, 1972:117)

Иако не наводи, можемо да претпоставимо, као и за воз „Женева-Париз у 8.45“, да је могао да да назив и улици, нпр. „Булевар тај и тај“, и да устврди да њен идентитет остаје исти у географском смислу, у односу на друге улице, чак и кад је њен материјални састав и изглед сасвим измењен. Једном установљен арбитрар- 
на веза измежу ознаке и означеног постаје важећа за припаднике језичке заједнице. Међутим, за разлику од већине језичких јединица, мотивисаност назива неког географског објекта (као уосталом уопште личних имена и свега другог што спада у ономастикон једног језика) представља специфичан слој језиког вокабулара и постаје предметом расправа пре свега, социолингвистичких.

Топономастика - лингвистичка дисциплина. Без намере да овде одређујемо и дефинишемо топономастику, желимо да истакнемо низ тема које се у ономастици традиционално посматрају, а обухватају готово све језичке нивое. Тако на фонолошком плану може доћи до промена акцента у случају именовања улица неком постојећом лексемом: упор. Душанова карава$\bar{u} а$ и Душанова улица - мења се и место и тип акцента. На нивоу творбене морфологије могу се анализирати творбени модели, нпр. сложеница: Беоірag, Царuірag, Пейpoīpag с обзиром на тип прве и друге компоненте или форманта у сложеници; поставити питање назива ктетика везаних за име места: Дорћолаи, Новобеоірађанин, Вожяованин, Звездараи?, или Чукараи?, становник Бановог брда? Несигурност у давању одговарајуђих назива још више истичу значај радова који се баве оваквом проблематиком са нормативног становишта (Брборић, 2009 и 2013). Затим ту су и питања језичких контаката, ког су порекла нека имена, односно њихова етомологија, што је интересантно и са интердисциплинарног становишта, јер се некада имена, поготово значајнијих простора, много дуже чувају од самог места или од неког обележја које је мотивисало име: Житиорађа, Алексинаи, Ниш, Беоіраg - за свако од ових имена можемо поставити питање када су настали, да ли су тако названи по физичком или неком другом обележју, и да ли нам нешто говоре о материјалној или културној 
прошлости. За практичну језичку употребу опет значајно је како транскрибовати или транслитеровати име неког страног града, с једне стране, или како настају, с друге стране, егзоними (од чешког Праха у српском је Праї, Венеција и ктетик Млетак уместо Венет или нешто слично, како је српско Беч постао назив за аустријски главни град и сл.). Морфологија такође може бити релевантна - да ли су називи у једнини или множини: тако је рецимо могуће да се нађе на интернету и „смештај у Кремни“, „смештај у Кремнима“, а исправна је ова друга синтагма ${ }^{1}$ јер су Кремна заправо множински облик. Или да ли је нека раднја у „Ђуке Динић“ или „Буке Динића“? Исправна је прва варијатна јер се ради о женској особи, а то само упућени у личност знају. На семантичком плану, може се размишљати о томе да ли су називи настали путем метафоризације или метонимизације, односно како тече процес категоризације уопште и концептуализације неког објекта и да ли такви процеси имају везе са давањем имена. Све су то примери тема које интересују не само ономастичаре и лингвисте већ и друге стручњаке, па и лаике.

Језички пејзажи и социолингвистика. Једна од посебности ономастикона јесте чињеница да се људи и предмети именују и обележавају експлицитним „конвенцијама“. Углавном се зна датум именовања, ко је именовао и најчешће то име има социјалну, или неку другу, промотерску функцију. Отуда се уз анализу имена у, пре свега, урбаним срединама, везује испољавање односа моћи и потчињености, класног раслојавања, а кроз: имена ресторана и хтела, малих и великих пословних институција, малих и великих продавница,

1 На шта је упозорио колега Милан Крсмановић, пореклом из Кремана, када је први аутор овог рада једном приликом употребила погрешан облик, на чему му се захваљујемо. 
супермаркета, библиотека, државних административних институција, адвокатских канцеларија, занатских радњи, апотека, и сл., све те институције, јавне и приватне добијају називе с циљем да се издвоје од других и јасно и атрактивно прикажу своју намену. Њихово именовање је релативно слободно (осим ако име није „погрдно“, или се њиме „вређа морал“ или је „у супротности са обичајима или схватањима средине“ - члан 343 Породичног закона Србије, што, претпостављамо, важи за именовања свих других установа и објеката). Поред овакве „микротопонимије“, за социолингвистику (а и друге дисциплине) битни су и називи улица, тргова, кејова (ходонима), чија се имена одређују углавом од стране политичко-административних управа општина или градова.

Сви наведени случајеви, сматра се, имају функцију утвршивања идентитета групе, појединца, установе, а иза сваког именовања стоје неке социјалне структуре за које име представља и симбол који „урезују“у физички простор.

Неколико тема, чини се, доминирају у литератури о читању градског текста: заступљеност језика у мултилингвалним срединама, идеолошка ревизија историје и промена назива.

Када се говори о првој теми, јасно је да се углавном ради о свим разноликим ситуацијама у којима се једним истим простором крећу говорници различитих језика, што, као што је општепознато, није нимало редак случај у свету. Једно је констатовати табле са називима и натписима на два језика или више језика, поготово ако су у питању вишенационалне или вишеетничке средине, када су оне симбол једнакости или надмоћи једног језика или другог и евентуално утврдити квантитативно проценте употребе, али то још 
увек није нужно корелатив са стварном једнакошћу у пракси. Један вид таквог раскорака налазимо у раду са веома индикативним насловом „Linguistic Landscape in Mixed Cities in Israel from the Perspective of 'Walkers': The Case of Arabic" (Trumper-Hech, H., 2010). Дакле, основна идеја у овом раду је да се упореди слика коју о употреби арапског и хебрејском у језичком пејзажу једног града (Северног Назарета) имају арапски и јеврејски становници са стварном сликом која се може документовано анализирати и снимити и како те две групе становника „виде“ употребу два језика у граду. На основу интервју са случајним узорком популације (путем око 300 телефонских интервјуа), утврђује се њихова перцепција. Пошто се простор може посматрати као изграђени артефакт, архитектонска и грађевинска стварност, затим као планирани простор како га градске власти и урбанисти замишљају и на крају, као простор у коме се живи, тј. простор у коме се крећу житељи града., поставља се питање какав је однос између стварног физичко'географског простора и оног у коме живе житељи.

На основу анализе констатује да постоје значајне разлике између припадника двеју група. Огромна већина јавних натписа су на хебрејском, нешто мање их има двојезичних, на хебрејском и енглеском, а врло мали проценат на два „домаћа“ језика, арапском и хебрејском (или евентуално и енглеском). То је стварна језичка слика. Узгред, тамошњи правни прописи подстичу да у свим градовима са мешаним становништвом постоје натписи на оба језика. Међутим, припадници двеју група различито перцепирају ту стварност употребе два језика. Према интервјуима, далеко више арапских испитаника сматра да натписи из приватне и јавне сфере садрже оба језика него што то мис- 
ле јеврејски испитаници. Овакви и други резултати анкете показују, по мишљењу аутора рада, да различити испитаници односно групе испитника друкчије перцепирају исти простор у зависности од свог историјског и друштвеног статуса. Јавни простор, односно језички пејзаж се види на различите начине, у контексту свог начина живота и своје културе. Једно логично објашњење јесте да се свака од група креће у некој својој сфери и употребу језика у иначе идентичном језичком пејзажу види у зависности и од свог физичког кретања (већина арапаског становноштва проводи време у својим, „арапским“ срединама-просторима) и од система вредности које њихова култура садржи. Когнитивне мапе простора су „невидљиве, субјективне и личне или интерперсоналне“ за разлику од реалних мапа географских простора (Trumper-Hech, 2010:247).

Друга тема тиче се језичких промена у језичком пејзажу. Флуидност, диверсификација, нови стилови, моде, мешање језика, нове институције, продавнице, производи, све то чини да се град не види као статичан текст, већ као врло динамичн, готово хаотичан феномен. Отуда свакако и интересовање за промене језилких пејзажа у литератури.

О томе је врло занимљив рад написала Смиљка Стојановић (2009). Њен текст је критички интониран, сматра да су промене насилне и супротставља идеолошке ставове власти и ставове популације. Комисије, сматра она, углавом сунанонимне, а власт их оснива. Уствари, комисије које бира град или општина обично буду у службеном спису, гласнику града, али нјихова имена нам мало говоре, јер су чланови углавном не много познати, и одборници су града/општине из редова различитих партија и они доносе одлуку да ли је нека личност довољна „заслужна да добије своју ули- 
цу“. Брига државе за називе улица и њихово прецизирање бројем итд., је разумљива, јер свеколики послови државне админстрације захтевају одређени тип кодирања који се у различитим геополитичким просторим остварују (наплате, порези, услуге здравствене, полицијске и сл.). Нешто што свакако олакшава живот организованог друштва. (Rose-Redwood, 460).

Али, „Људи се разликују по своме ставу према промени назива улица. Ставови се, као и сви аспекги спознаје и осећања код људских бића развијају рано у детињству и резултат су ставова родитеља и вршњака, контакта са другим људима који се на много начина разликују као и различитих емотивних сусрета и искуства.Ти ставови чине део представе о себи, о другима и о култури у којој појединац живи", каже С. Стојановић (Стојановић, 2008:167). Морамо приметити ипак. Да ставове оформљују и институције, школа, власти, медији. Промене које она наводи су сасвим у складу са оним што се дешавало у свим земљама у „транзицији“ од комунистичког система ка новим системима, али не само шима. Називи и имена и шихове промене рефлектују борбу између различитих политичких група у различитим земљама и различитим временима. Сећање на одговарајућу личност није никаква новина као потреба да се оно продужи, те уклањање споменикастатуа и имена једних јунака и хероја замени новим, да се стварају нове „приче“ о историји и указује част новим херојима, јунацима, нормалан је процес и не први пут виђен у историји. Једноставно се ствара нови културни капитал којим се може подичити одређена средина. Ипак став ауторке је негативан, и с разлогом: „Нестајала су имена народних хероја из Другог светског рата и замењивана именима краљева и краљица из националне историје, именима сарадника окупатора,чак и зли- 
коваца, кољача или њихових идеолога“ (Стојановић, 2010: 168).

Наводи примере промена из центра града Београда, између осталих како је Булевар револуције постао поново је Булевар краља Александра као пре доласка комуниста на власт, Булевар Црвене армије је Јужни булевар,Улица генерала Жданова је Ресавска. Сматрам да би осим идеолошких критерија требало имати на уму и друге елемент. Наиме, враћање старих назива има занимљиве реперкусије на генерације становништва. Док су генерације рођене и одрасле после другог светског рата често с неразумевањем слушале старију генерацију када говоре да се нешто или неко налази у Дечанској, Крунској или Зориној (Кнегиње Зорке), нове генерације одрасле с новом-старом номенклатуром сигурно неће разумети ако чују „Генерал Ждановој“ или „Булевар Црвене армије“. Сигурно има места неком истраживању које би испитало како неки називи опстају: Рецимо, да ли краћи називи дуже трају, те су и „Зорина“ и „Дечанска“ биле једноставније од дужих „Ивана Милутиновића“ и „Моше Пијаде“, као што и данас на радију такси службе врло често кажу само „Револуције“ иако је већ одавно враћен назив Булевар краља Александра.

С обзиром да се у промени назива улица „уочава борба за центар, односно за главне улице“, за очекивати је да су се у споредним улицама понекад задржали и народни хероји из другог светског рата. Тако се улица Ђуке Динић, (претходно Расињска улица) а по народном хероју пореклом из Лесковца, која је као члан Комунистичке партије прешла почетком Другог светског рата по задатку у Београд, 1942. ухапшена, одведена у Јајинце где је стрељана 1943, задржала до данас своје име. Нешто је лошије прошла, једна друга, споредна, 
улица Филипа Кљајића, такође народног хероја, комесара Прве пролетерске дивизије, такође погинулог 1943., а супруга наведене Ђуке (Ђурђелине) Динић, која је постала улица Патријарха Варнаве.

Специфична решења су дељење улица када се одлучи да је још једна личност „заслуђила“ уливу. Тако је у Ново Саду одлучено да ће се нови део улице Ленка Дунђерски звати по Милки Иви 27 марта, у насељу Сунчани брег део нове улице не понесе име Ленке Дунђерски, као њен наставак, него да то ипак буде посебна улица и да се назове по професорки Филозофског факултета Милки Ивић. У Београду је улица 27. марта пресечена како би се вратило историјско памћење од пре другог светког рата, те је сада пола улице Краљица Марије. Да ли су то мудра решења треба питати онога који покушава да ли је студентски дом (некада по имену Краљице Марије) у једној или другој улици.

Промене имена улице нису само идеолошког типа, већ и често на националној основи. Примера за такве промене, ревизије националне историје у новонасталим државама после распада социјалистичких држава има много, а ми ћемо навести само неколико. На првом месту, издвојићемо посебно занимљив контраст који Стојановић наводи у вези са Бања Луком и Сарајевом: "Наиме, Марију Бурсаћ, народног хероја српског порекла, у Бањалуци задржавају, а гледају да избаце Вахиду Маглајић, Муслиманку. У Сарајеву раде обрнуто: избацили су Марију Бурсаћ, а задржали Вахиду Маглајић у називу улице“ (Стојановић, 2008:171).

Сличних примера има готово на сваком кораку на Балкану. Тако је у трагању за националним идентитетом Македонаца, владајућа партија ВМРО покренулапре свега архитектонски пројекат изградње Скопја, и то на начин који ће „антиквизирати“, како су говорили 
критичари, а по идеолозима уствари „ујединити македонску историју и допринети већем националном поносу Македонаца“. Један од потеза у том правцу је било реименовање аредорома Петровец у Аеродром Алесандар Македонски, као и реименовање аутопута Братсво и јединство у аутопут такође Александра Македонског. (Risteski, 2016)

Од града-списка ка граду као кохерентном тексту. Ако већина научника из разних дисциплина данас сматра да је именовање места, „објеката и „артефаката“" и њихове етимологије, које су изгледа доминирал традиционалном топономастиком, превазишло такав период, те се окреће просторној пракси која не види топониме као проста имена дата постојећим физичким објектима, већ смисаоне когнитивне, људске и културне феномене, онда је то сасвим очекиван правац. Другим речима, овај аутор сматра да „систем именовања“ заправо „културна арена“, у коме именовање места део размене и „промета културних идеја“, предмет спознаје, нешто што се моће истраживати и читати/тумачити. (Rose-Redwood, 2010:456)

Мислимо да сваки појединац и свака група заправо креира своје текстове из ономастикона свога града (или села, краја). Онима који имају моћ социјалну да дају имена окренута је пажња, јер они и настоје и често успевају да наметну своје виђење друштва и његове хијерархије вредности. Али и они који немају ту моћ, уколико им имена постану симболички „капитал“ против кога ће се борити учиниће то на разне начине. Сами ће дописивати својим језиком, својим именом, прецртавати непожељно (сетимо се да је табла са натписом Титово Ужице на магистрали дуго времена стајала за затамњеном првом компонентом, јер власт очито није била довољно ажурна) и такве „битке“ за своје натписе 
водиће се где год има етничких, идеолошких, сукултурних несугласица било где у свету.

Но, оно што је најважније јесте да ли треба град посматрати као текст или као скуп текстова које бирамо. Јер, као што ниједан појединац не зна све речи и све текстове /дискурсе свог језика и културе, а још мање неког страног језика, тако ни град као текст не можемо посматрати као номенклатуру топонима. Град је пре скуп текстова, мешусобно повезаних вредностима које успоставлја на хоризонталној и вертикалној оси, врло слично језичком систему. Ако су нам имена тешка, рецимо морамо да се крећемо по страном граду, где треба запамтити низ нових назива и тек створити хијерархију, искористићемо позната имена, па ћемо у њему (Паризу, Истамбулу, ...) део града који је „раднички“ назвати „Раковицом“, удаљени кварт од центра „Бановим брдом“ или „Браћом Јерковић“, а модерни део „Нови Београд“.

О сличном феномену пишу (Rose-Redwood et al., 2010:453-454) наводећи пример америчких војника који су се тешко сналазили у освојеном Багдаду, те су арапске називе замењивали својим називима: California Street', 'Virginia Avenue', 'Main Street', те су и на својим војничким мапама додавали управо та имена како би се лакше сналазили.

Систематизовање града као кохерентног текста, или да употребимо де Сосиров израз, „кохерентног система“" ствара сваки појединац који се креће у свом граду. Више од двадесетак улица у својој околини тешко да можемо да „мапирамо“ именима, а и оне које не можемо обично су улице које спајају две познатије улице, и готово сваку везујемо њеним специфичним културолошким значењем значењем за нас (улица где је шустер, пролаз где је фризер, ...)

Као што језик служи да систематизујемо ствар- 
ност, тако се и когнитивно, социјално и друго мапирање простора помоћу језика успешно остварује. И то би требало да постане такође једна од важних тема истраживања језичког урбаног пејзажа. Упоредићемо са једним другим семиотичким, а генијалним изумом, насталим почетком двадесетог века. Енглески електроинжењер, Хари Бек (Harry Beck), створио је систем представљања односа између линија и станица Лондонског метроа. Све претходне мапе су „сликале“ географски тачне путање, раздаљине и односе између станица, које су у стварности толико испреплетане и кривудаве да нико није могао да их користи. Бек је схватио да путнике не интересује како кривуда и са чим је испреплетана путања којом иде воз у стварности, већ га интересује само да уђе у прави воз (праву линију) и да стигне од места А до места Б. Мапа коју је овај инжењер направио уопште није мапа, већ је само шема релевантних апстрактних односа који су функционални за путника. По том моделу су све друге мапе светских метроа направљене.

Отуда сматрамо да је лингвистика урбаних језичких пејзажа с правом посвећена проучавању социјалних и културних, мултилингвалних мапирања, али да још више посвети пажње како изворни говорник „чита“ град: као текст. Иако у текстовима града доминира топономастички систем, он се претвара у систем „идентитета и вредности“ који сваки учесник даље претвара у свој кохерентни текст.

\section{Literatura}

Backhaus, P. (ed.), 2007. Linguistic landscapes: A comparative study of urban multilingualism in Tokyo. Clevedon, UK: Multilingual Matters. 
Backhaus, P. (2007) Linguistic Landscapes. A comparative Study of Urban Multilingualism in Tokyo, Multilingual Matters LTD. Clevedon, Buffalo, Toronto

Gorter, D. (ed.) (2006) Linguistic Landscape: A New Approach to Multilingualism. Multilingual Matters LTD. Clevedon, Buffalo, Toronto.

Landry, R., \& Bourhis, R. Y., 1997. Linguistic landscape and ethnolinguistic vitality: An empirical study. Journal of Language and Social Psychology, 16(1), 23-49.

Leko, M. (2006) Beogradske ulice i trgovi : 1872-2006, Beograd : Zavod za udžbenike.

Mitchell, Jerry T. and Alderman, Derek H., 2014. A Street Named for a King: The Politics of Place-Naming, Social Education 78(3), pp 123-128.

Risteski, Lj. 2016. Monuments and urban nationalism. The Skopje 2014 project, Antropologija 16, sv. 3, 49-70.

Rose-Redwood, R. 2008. 'Sixth venue is now a memory': Regimes of spatial inscription and the performative limits of the official city-text. Political Geography, 27 (8), pp. 875894.

Rose-Redwood,R., Alderman, D. and M.Azaryahu, 2010. Geographies of toponymic inscription: new directions in critical place-name study. Progress in Human Geography 34(4) (2010) pp. 453-470

Shohamy, E. G. (ed.), 2006. Language policy: Hidden agendas and new approaches. London: Routledge.

Shohamy, E., Ben-Rafael, E. and M. Barni (eds.), 2010. Linguistic Landscape in the city, Multilingual Matters LTD. Clevedon, Buffalo, Toronto

Shohamy-Gorter (eds.), 2009. Linguistic Landscape. Expanding the Scenery. Routledge. New York and London,.

Trumper-Hech, N. 2010. Linguistic Landscape in Mixed Cities in Israel from the Perspective of 'Walkers': The Case of Arabic, 235-252. In: Shohamy, Elana, Eliyer Ben-Rafael, Monica Barni (eds.) (2010), Linguistic Landscape in the city. Clevedon, Buffalo, Toronto: Multilingual Matters LTD.

Брборић, В. 2009. "Називи насељених места, њихови етници и ктетици у правописним речницима српског језика”, 
Развојни йрочеси и иновачије у срйском језику, 1 (2009), стр. 327-339.

Брборић, В. 2013. "Писање етника и ктетика у Правопису и Правописном речнику", Срйски језик и њеїови ресурси: Теорија, ойис и йримене, Београд, 75-84.

Стојановић, С. (2008), Ходонимијске метаморфозе или о преоблачењу улица. Срйски језик. 13/1-2, 163-179.

Reuben Rose-Redwood, Derek Alderman and Maoz Azaryahu, Geographies of toponymic inscription: new directions in critical place-name studies

Ferdinand de Saussure, Cours de linguistique générale. Edition critique, ed. \& comm. Tullio de Mauro, Paris, 1972.

Prof. Vesna Polovina, $\mathrm{PhD}$

Prof. Maja Đukanović, PhD

\title{
CITY AS A TEXT
}

\begin{abstract}
Summary
Based on texts about and in Belgrade urban space, the social and cultural place of an individual and/or social group is studied in this paper. We begin with the linguistic (toponomastic) landscape of streets, the "meanings" these street names might have for the inhabitant, compare with some features of other sities described in literature, and illustrate with texts depicting the significance of the names. We conclude that the geographical space and the constructed texts cannot be correlated unless the functionality of the linguistic text is taken into account.
\end{abstract}

Key words: text, city, linguistic landscape 